\title{
PENINGKATAN KEGIATAN BELAJAR PESERTA DIDIK MATA PELAJARAN PENDIDIKAN AGAMA ISLAM MELALUI IMPLEMENTASI MANAJEMEN KELAS
}

\author{
Asep Kurniawan \\ Institut Agama Islam Negeri Syekh Nurjati Cirebon \\ Email: asepkurniawan@ syekhnurjati.ac.id
}

\begin{abstract}
ABSTRAK
Penelitian ini ditujukan untuk mengetahui sejauh mana peningkatan kegiatan belajar peserta didik mata pelajaran pendidikan Agama Islam melalui implementasi manajemen kelas di MTsN 1 Kota Cirebon. Penelitian ini adalah mixed method. Dalam penelitian kualitatif subyek penelitian yaitu 3 orang guru PAI dan siswa-siswa kelas 8. Instrumen yang digunakan adalah wawancara mendalam, observasi mendalam, dokumentasi. Teknik analisisnya menggunakan reduksi data, display data, dan penyimpulan data. Sementara itu dalam penelitian kuantitatif populasi 10 dan 939 siswa dengan proportionate stratifield random sampling, yakni 47 siswa. Instumennya adalah angket. Uji coba instrumen ditempuh melalui validitas dan reliabilitas. Tekhnik analisis menggunakan uji t. Temuan penelitian secara kualitatif menunjukkan bahwa implementasi manajemen kelas dalam proses belajar mengajar PAI sudah berjalan cukup baik. Sementara itu secara kuantitatif menunjukkan bahwa (1) implementasi manajemen kelas dinilai positif dengan persentase rerata sebesar $76.30855 \%$ > $75 \%$, (2) kegiatan belajar siswa dinilai positif. Hal ini ditunjukkan dari persentase rerata sebesar $83.0924848 \%>75 \%$, (3) implementasi manajemen kelas positif dapat meningkatkan kegiatan belajar siswa secara signifikan. Hal ini ditunjukkan dari nilai yang didapatkan lebih besar dari nilai yang dikeluarkan $1>0.928231747$.
\end{abstract}

Kata kunci: Manajemen kelas, aktivitas belajar, guru, siswa

\section{ABSTRACT}

This study aimed to determine the extent of the increase in learning activities of Islamic education subjects through the implementation of classroom management in State Islamic Junior High School 1 Cirebon City. This study used a mixed-method. In qualitative research, the research subjects were 3 Islamic education subject teachers and 8th-grade students. The instruments were in-depth interviews, in-depth observations, and documentation. The analysis technique was taken through reducing data, displaying data, and concluding data. Meanwhile, in quantitative research, the population is 10 teachers. $5 \%$ of 939 students, proportionate stratified random sampling, were 47 students. The instrument was a questionnaire. The instrument trials were carried out through validity and reliability. The analysis technique was the t-test. The qualitative research findings indicated that the implementation of classroom management in the teaching and learning process ran quite well. Meanwhile quantitatively shown that (1) the implementation of class management was 
positive with the average percentage was $76.30855 \%>75 \%$, (2) student learning activities were positive. It was indicated from the average percentage was $83.0924848 \%>75 \%$, (3) implementation of classroom management could significantly enhance student learning activities. This was indicated from the obtained value was greater than the issued value, which was $1>0.928231747$.

Keywords: Class management, learning activities, teachers, students

\section{A. Pendahuluan}

Pendidikan adalah aspek yang sangat penting untuk membangun masa depan. Oleh sebab itu, pendidikan berperan mensosialisasikan kompetensi baru kepada mereka agar dapat mengantisipasi tuntutan masyarakat yang senantiasa berkembang. Pada dasarnya pendidikan dilaksanakan untuk merespon tuntutan masyarakat. Pendidikan ialah Pendidikan Agama Islam (PAI), tidak hanya menyampaikan pengetahuan mengenai agama Islam, namun yang lebih penting lagi adalah menanamkan keimanan, ketakwaan dan akhlak mulia serta pola pikir yang sejalan dengan nilai-nilai mata pelajaran Pendidikan Agama Islam. ${ }^{1}$

Sayangnya berpijak penelitian survei PPIM UIN Jakarta terhadap guru-guru agama di berbagai sekolah (MA, SMA, dan SMP, dan MTs) di Tangerang Selatan dan Jakarta menemukan fakta bahwa "pengajaran Pendidikan Agama Islam oleh guru-guru agama kurang menarik bagi para peserta didik, sehingga membosankan dan monoton, ${ }^{2}$ sehingga cenderung diabaikan oleh para siswa dan kurang diiringi dengan perkembangan ilmu pengetahuan dan teknologi. Padahal hal tersebut sangat diperlukan untuk menjadikan siswa yang kuat spiritual dan mempunyai akhlak mulia.

Gurulah yang paling dekat dan bertanggung jawab terhadap para siswa di sekolah, sehingga guru menjadi aktor penting dalam penciptaan suasana pembelajaran yang kondusif bagi peningkatan hasil belajar siswa. Dengan kata lain, guru akan mempunyai porsi terbesar dalam memberikan kontribusinya terhadap kualitas pendidikan. ${ }^{3}$ Guru yang

\footnotetext{
${ }^{1}$ Ade Imelda Frimayanti, 2017. "Implementasi Pendidikan Nilai dalam Pendidikan Agama Islam". alTadzkiyyah: Jurnal Pendidikan Islam, 8 (2), 227-245.

${ }^{2}$ Munawar Rahmat Budi dan Aceng Kosasih. 2015. "Efektifitas CD Interaktif dalam Pembelajaran Pendidikan Agama Islam untuk Meningkatkan Hasil Belajar Siswa SMP”. Jurnal Pendidikan Agama Islam- Ta'lim, 13 (2), 191-200.

3 Rehaf A. Madani, 2018. "Analysis of Educational Quality, a Goal of Education for All Policy", Higher Education Studies, 9 (1), h. 100.
} 
baik ialah guru yang sukses dalam pengajaran. Guru yang sukses dalam pengajaran ialah guru yang dapat mempersiapkan para siswa mencapai tujuan yang sudah ditetapkan dalam kurikulum melalui manajemen kelas sehingga kegiatan belajar PAI siswa di dalam kelas dapat berlangsung dengan baik dan terhindar dari berbagai gangguan yang bisa berdampak negatif bagi para siswa. Kegiatan belajar siswa melalui manajemen kelas bisa menjadi dinamis dalam emosi siswa, mental, sikap, perbuatan, dan bentuk perilaku. Oleh karena itu, manajemen kelas ialah bagian yang tidak dapat dipisahkan dari kemampuan-kemampuan profesional yang mesti dimiliki oleh seorang guru. ${ }^{4}$

Guru PAI sebagai 'sutradara' pembelajaran, bertugas menggerakkan, merangsang, memimpin, menciptakan situasi, dan mengarahkan aktivitas pembelajaran sejalan dengan rencana. Pembelajaran bisa berjalan secara efektif jika guru bisa menjalankan perannya sebagai pelaksana pembelajaran PAI yang bisa mengelola aktivitas pembelajaran yang efektif sejalan dengan rencana.

Mayoritas guru yang telah memiliki banyak pengalaman berpandangan bahwa kegiatan belajar mengajar sebaik apapun dan selengkap apapun apabila tidak diiringi dengan keterampilan manajemen kelas, maka kegiatan belajar mengajar tersebut akan menjadi percumah.

Hal ini dapat difahami, karena keterampilan manajemen kelas adalah diantara keterampilan dasar mengajar yang bertujuan untuk merealisasikan dan menciptakan kondisi pembelajaran yang maksimal. ${ }^{5}$ Itu artinya kemampuan ini kuat kaitannya dengan kompetensi profesional guru untuk membuat kondisi yang menyenangkan, menguntungkan para siswa dan menciptakan kedisiplinan belajar yang sehat.

Berdasarkan penelitian pendahuluan ${ }^{6}$, penulis mendapati strategi manajemen kelas sudah cukup efektif yang berdampak pada kegiatan belajar para siswa secara optimal. Para siswa dinilai aktif dalam belajar, diakibatkan diantaranya oleh kompetensi guru yang baik pula dalam manajemen kelas. Hal ini sejalan dengan ini penelitian Imran Latif Saifi, et al. ${ }^{7}$

${ }^{4}$ Helen M. Egeberg, Andrew McConney, Anne Price. 2016. "Classroom Management and National Professional Standards for Teachers: A Review of the Literature on Theory and Practice. Australian Journal of Teacher Education, 41 (7), 1.

${ }^{5}$ Katharina Sieberer- Nagler. 2016. "Effective Classroom-Management \& Positive Teaching”, English Language Teaching, 9 (1), h. 163.

6 23-24 September 2019.

7 Imran Latif Saifi, Muzaffar Hussain, Lubna Salamat, Mohammad Iftikhar. 2018. "Impact of Classroom Management on Students' Achievment at University Level”, Asian Journal of Social Sciences \& Humanities, 2 
Untuk itu, penelitian ini penting dan perlu untuk ditindaklanjuti guna mengungkap secara lebih mendalam lagi mengenai implementasi manajemen kelas di MTsN 1 Pilang Kota Cirebon.

\section{B. Tinjauan Teori}

1. Manajemen Kelas

Proses pembelajaran akan senantiasa terselenggara dalam sejumlah aktivitas di kelas. Program pembelajaran kelas itu harus diciptakan dan dikembangkan menjadi wahana bagi terciptanya pembelajaran yang efektif. Hal tersebut tentu saja mesti didukung oleh kompetensi guru $^{8}$ dalam manajemen kelas. Manajemen kelas diartikan sebagai upaya menciptakan dan memelihara kondisi belajar yang maksimal melalui perencanaan, pengorganisasian, memimpin, dan mengendalikannya jika ada gangguan dalam proses pembelajaran melalui desain lingkungan fisik kelas, penciptaan lingkungan positif untuk pembelajaran, penegakan aturan, pelibatan siswa dalam kerjasama, pemecahan masalah secara efektif, dan penggunaan strategi komunikasi yangbaik serta evaluasi.

Unsur manajemen kelas bagi guru masih dipandang sebagai suatu aktivitas yang bersifat sekunder dibanding pengajaran. Padahal, jika mempertimbangkan kepentingannya, kedua hal tersebut adalah aspek yang sangat mempengaruhi efektivitas pembelajaran. Untuk itu, hal ini tidak bisa diabaikan. Aspek kritis kesuksesan pengelolaan kelas ada pada penerapan teknik-teknik dan pendekatan-pendekatan kontrol dan disiplin kelas. ${ }^{9}$ Artinya bahwa kontrol dan disiplin kelas adalah bagian dari manajemen kelas.

Manajemen kelas yang efektif pada akhirnya akan berdampak pada kondisi pembelajaran menjadi kondusif sehingga dapat mendukung terciptanya lingkungan yang membuat instruksi guru menjadi jelas dan efektif. Manajemen kelas yang baik bisa memotivasi siswa dalam melakukan kegiatan belajar secara maksimal. ${ }^{10}$ Sejumlah analisis penelitian pendidikan yang dilaksanakan dalam lima puluh tahun terakhir secara jelas mengungkapkan kemampuan guru dalam mengelola kelasnya mempunyai efek

(2), 13-27.

8 Banerjee, Sarmila, Atasi Mohanty, Namita Das. 2014. "Impact of Teacher Competence and Teaching Effectiveness on Students' Achievement in Life Science Subject at the Upper Primary Stage". Journal of Indian Education, 29 (4), 29-48.

${ }^{9}$ Ritu Chandra, 2015. "Classroom Management for Effective Teaching". International Journal of Education and Psychological Research, 4 (4), 13-15.

${ }^{10 R i t u}$ Chandra, 2015. "Classroom Management for Effective Teaching". International Journal of Education and Psychological Research, 4 (4), h. 13-15. 
paling dramatis dibanding dengan faktor-faktor lain. Manajemen kelas yang efektif meningkatkan keterlibatan aktivitas peserta didik, menurunkan perilaku yang merusak, dan memberikan manfaat bagi waktu belajar peserta didik. ${ }^{11}$

Penelitian Katharina Sieberer-Nagler ${ }^{12}$ yang menunjukkan adanya hubungan signifikan antara disiplin yang baik, organisasi kelas dan pengajaran yang optimal. Menurutnya, guru yang berhasil dalam mengelola perilaku buruk di ruang kelas, menjaga hubungan baik dengan peserta didik, mendorong disiplin diri dan martabat, dan melibatkan orang tua, teman sebaya siswa serta guru lain dalam proses pembelajaran. Melibatkan semua orang yang dekat dengan pelajar sangat penting dalam mendorong pelajar untuk menerima otoritas guru dan membangun hubungan kelas antarpribadi yang diperlukan.

Hamid Tohidi membedakan antara tindakan-tindakan pengelolaan kelas dengan motivasi, karena motivasi itu adalah kunci dari efektifitas pembelajaran di kelas. ${ }^{13}$ Walaupun begitu, manajemen kelas yang diterapkan dengan baik memudahkan tercapainya kontrol dan disiplin kelas yang baik pula.

Manajemen kelas dikaitkan juga dengan kegiatan belajar siswa, merupakan sejumlah aktivitas yang berproses melalui interaksi siswa dengan pendidik dan sumber belajar di satuan pendidikan. Penerapan manajamen kelas dibutuhkan untuk memotivasi siswa belajar secara aktif. Konstruktivisme memfokuskan pada setiap siswa untuk aktif menyusun dan membangun (to construct) pengetahuan dan pemahaman. ${ }^{14}$ Untuk itu, guru tidak hanya memberikan informasi ke pikiran peserta didik, namun guru mesti memotivasi siswa untuk mengeksplorasi dunia mereka, menemukan pengetahuan, merenung, dan berpikir dengan kritis. Pandangan konstruktivis mengenai pembelajaran mengimplikasikan, bahwa guru tidak hanya berperan sebagai sumber belajar, namun pula berperan sebagai motivator bagi para siswa peserta didik untuk berperilaku

11 Oliver, R.M., \& Reschly D.J. Effective Classroom Management: Teacher Preparation and Professional Development. (Washington, DC: Vanderbilt University, 2007), h. 5.

${ }^{12}$ Katharina Sieberer- Nagler. 2016. "Effective Classroom-Management \& Positive Teaching", English Language Teaching, 9 (1), 163-172.

${ }^{13}$ Hamid Tohidi. 2012. "The Effects of Motivation in Education". Procedia - Social and Behavioral Sciences, 31, $820-824$.

${ }^{14}$ Steve Olusegun Bada. 2015. "Constructivism Learning Theory: A Paradigm for Teaching and Learning", IOSR Journal of Research \& Method in Education, 5 (7), 66-70. 


\section{belajar. $^{15}$}

\section{Kegiatan Belajar}

Kegiatan belajar Pendidikan Agama Islam diperlukan dalam belajar, karena belajar pada dasarnya ialah melakukan aktivitas untuk merubah perilaku. ${ }^{16}$ Belajar PAI ialah perubahan tingkah laku sebab latihan dan pengalaman dalam pengajaran dan penanaman materi-materi dan nilai-nilai agama Islam. Domain yang dirubah dalam belajar adalah kognitif, psikomotor, dan afektif. Kegiatan belajar dilihat dari sudut pandang guru PAI ialah perlakuan terhadap bahan ajar berupa aktivitas guru menjadikan siswa belajar. Sementara itu, belajar dilihat dari sudut pandang siswa ialah perlakukan terhadap materi pembelajaran PAI dalam wujud mempelajari ataupun berinteraksi dengan materi pembelajaran agama Islam. Pada hakekatnya, belajar adalah suatu kegiatan yang memuat unsur kesengajaan, baik faktor kesengajaan dari dalam individu yang belajar ataupun faktor kesengajaan dari luar individu yang belajar, yakni guru yang mendesain aktivitas pembelajaran.

\section{Metode Penelitian}

Penelitian ini adalah mixed method, yaitu penelitian yang menekankan pada pengumpulan data dengan memadukan data kualitatif dan data kuantitatif. Subyek penelitian dalam hal ini ialah 10 orang guru PAI (SM, WR, SM, MB, MH, YH, MS, DR, HZ dan MU) dan siswa di kelas 8 secara acak. Untuk guru PAI peneliti menggunakan purposive sampling dan memilih secara acak 3 orang guru PAI, yaitu WR, SM, dan MB. Instrumen pengumpalan menggunakan wawacara mendalam, observasi mendalam dan dokumentasi. Tehnik analisis yang ditempuh melalui pengumpulan data, reduksi data, display data, dan penyimpulan data. ${ }^{17}$ Sementara itu penelitian kuantitatif digunakan untuk memperkuat temuan kualitatif tentang implementasi manajemen kelas di MTsN 1 Pilang Kota Cirebon. Dalam hal ini, maka peneliti mengkaji data yang sudah terjadi sebelumnya untuk dianalisis dengan memakai perhitungan formula statistik. Penelitian dilaksanakan di MTsN 1 Kota Cirebon dari mulai tanggal 23 September sampai 2 November 2019.

\footnotetext{
${ }^{15}$ Jayeeta Bhattacharjee. 2015. "Constructivist Approach to Learning-an Effective Approach of Teaching Learning”. International Research Journal of Interdiciplinary \& Multidiciplinary Studies (IRJIMS), 1 (6), 65-74. 16 Sardiman, Interaksi dan Motivasi Belajar Mengajar. (Jakarta: RajaGrafindo Persada, 2018), h. 95.

17 Asep Kurniawan. Metodologi Penelitian Pendidikan. (Bandung: Remaja Rosdakarya, 2018), h. 241.
} 
Populasi berjumlah 939 siswa $^{18}$ dengan teknik sampel secara acak berstrata yang proporsional, yakni sebesar 5\% $(0.05 \times 939)=47$ siswa. Jumlah sampel ditetapkan menurut ukuran sampel. Instrumen utama pengumpulan data adalah angket tertutup. Instrumen angket yang sudah dibuat, kemudian diujicobakan untuk mengetahui validitas dan reliabilitasnya pada 20 orang di luar responden tetapi setara keadaannya dengan responden penelitian.

Terakhir adalah tekhnik analisis dan interpretasi data untuk mendapatkan gambaran implementasi penalaran pada proses penelitian, dilaksanakan untuk menguji hipotesis statistik. Berlandaskan pada jenis hipotesis statistik yang dibedakan atas hipotesis deskriptif dan hipotesis asosiatif, maka analisis data menggunakan teknik statistik inferensial dan statistik deskriptif. Pengujian hipotesis deskriptif dengan memakai formula statistik deskriptif dilakukan pada hipotesis deskriptif dirumuskan. Untuk itu, penulis menggunakan uji t (t-test) satu sampel untuk menguji hipotesis deskriptif terhadap data yang berbentuk interval atau ratio. Tehnik analisis yang digunakan dalam penelitian ini adalah tehnik analisis regresi sederhana untuk menguji hipotesis asosiatif antara variabel independen dengan variabel dependen. Dari hasil analisis ini, maka dapat dilakukan prediksi terhadap sejumlah nilai dalam variabel dependen akan terjadi jika nilai dalam variabel independen ditentukan. Hasil analisis data tersebut dipakai untuk membuktikan hipotesi dan menjawab rumusan masalah dan penarikan kesimpulan serta implikasi penelitian.

\section{Temuan dan Pembahasan}

1. Implementasi Manajemen Kelas

Pengaturan keadaan fisik sangatlah penting sebab keadaan tempat belajar yang menyenangkan berpengaruh terhadap kondisi belajar dan hasil belajar. ${ }^{19}$ Untuk itu guru PAI di MTsN 1 Kota Cirebon berupaya melakukannya dalam rangka mendukung peningkatan intensitas proses aktivitas belajar peserta didik dan ketercapaian tujuan instruksional.

Perencanaan

\footnotetext{
18 Dokumentasi MTsN 1 Pilang Kota Cirebon 2020

${ }^{19}$ Mohammad AAHM Ali. 2017. The Influence of the Physical Environment on Learning Behaviour: a Case Study of Intermediate Schools in Kuwait. Dissertation, Birmingham, UK: Faculty of the Arts, Design and Media, Birmingham City University, h. 40.
} 
Pada tahap perencanaan, berdasarkan wawancara ke beberapa guru PAI, WR, SM, dan MB, mereka mengakui bahwa sebelum pembelajaran, mereka mempersiapkan terlebih dahulu dengan membuat seluruh perangkat pembelajaran yang dibutuhkan. Mulai dari RPP, buku siswa, buku guru, dan media pembelajaran. Hal ini mereka lakukan sebagai acuan untuk memperlancar proses belajar mengajar di kelas agar para siswa dalam aktif secara positif dalam proses pembelajaran, menghilangkan perilaku negatif dan juga mempersiapkan kondisi psikis peserta didik saat mengawali kegiatan belajar mengajar. ${ }^{20}$ Artinya, apa yang ditemukan dalam penelitian ini terkait dengan yang dijelaskan oleh Oliver and Reschly bahwa pengelolaan perilaku ini menjadi bagian yang tidak terpisahkan dari perencanaan manajemen kelas yang didesain seorang guru secara komprehensif. ${ }^{21}$

Secara lebih rincinya, dalam tahap perencanaan dari manajemen kelas pembelajaran PAI di MTsN 1 Kota Cirebon dilaksanakan melalui: ${ }^{22}$

a. Penyusunan Silabus

Silabus yang dimaksudkan dari data di lapangan ini adalah sejumlah rencana dan pengaturan mengenai aktivitas pembelajaran, manajemen kelas, dan penilaian hasil belajar. Penyusunan silabus ini diselaraskan dengan karakter materi yang sejalan dengan kurikulum 2013 dan dipertimbangkan berpijak pada ciri dan kebutuhan daerah setempat, dalam hal ini Kota Cirebon. Selanjutnya diselaraskan pula dengan potensi, kebutuhan, dan karakteristik siswa.

Silabus ini disusun oleh setiap guru mata pelajaran Pendidikan Agama Islam untuk membantu guru tersebut dalam menjabarkan kompetensi dasar menjadi bentuk perencanaan belajar mengajar, yaitu meliputi kompetensi apa yang hendak dikembangkan pada peserta didik.

Temuan di atas sejalan dengan yang dijelaskan oleh I Made Alit Mariana bahwa silabus adalah penjabaran standar kompetensi dan kompetensi dasar ke dalam materi pokok/pembelajaran, aktivitas pembelajaran, dan indikator pencapaian

\footnotetext{
${ }^{20}$ wawancara 1 Oktober 2019

${ }^{21}$ R.M. Oliver \& Reschly D.J. Effective Classroom Management: Teacher Preparation and Professional Development. (Washington, DC: Vanderbilt University, 2007), h. 8.

${ }^{22}$ wawancara 7 - 11 Oktober 2019
} 
kompetensi bagi penilaian. ${ }^{23}$

b. Menyusun RPP

Menyusun Rencana Pelaksanaan Pembelajaran (RPP) dilakukan sebelum pembelajaran berlangsung. Hal ini dianggap penting oleh guru-guru PAI dalam proses belajar mengajar, karena melalui penyusunan RPP tersebut, guru-guru PAI di MTsN 1 Kota Cirebon merasa lebih percaya diri dalam berinteraksi dengan peserta didik di dalam kelas. Alasannya, mereka memiliki acuan dalam mengajar. Pembuatan rencana pelaksanaan pembelajaran ini disejalankan dengan karakter materi PAI yang sejalan kurikulum 2013 dan dipertimbangkan berpijak pada kebutuhan dan ciri daerah setempat atau Kota Cirebon. Selanjutnya diselaraskan pula dengan kebutuhan, potensi, dan karakteristik siswa. Hal tersebut dilakukan sebelum implementasi manajemen kelas untuk mendapatkan dan mencapai tujuan pembelajaran yang semaksimal mungkin.

c. Pembuatan Sejumlah Perangkat yang Lain (kurikulum 2013, prota, promes, bahan/program yang mesti dipelajari, pedoman belajar, dan lain-lain)

Berbagai hal yang juga bisa mempengaruhi pembelajaran PAI di MTsN 1 Kota Cirebon ialah pembuatan instrumen pembelajaran seperti kalender pendidikan, prota, promes, dan pedoman belajar. Terkait dengan kurikulum yang dipakai, di MTsN 1 Kota Cirebon menerapkan kurikulum yang baik dan cukup seimbang, yakni Kurikulum 2013 yang dinilai sejalan dengan kebutuhan peserta didik masa kini. Pengembangan Kurikulum 2013 yang mengarah kepada standar nasional pendidikan ditujukan guna menjamin tercapainya tujuan pendidikan nasional. Standar nasional pendidikan meliputi standar isi, standar proses, standar kompetensi lulusan, standar pendidik dan tenaga kependidikan, standar sarana dan prasarana, standar pengelolaan, standar pembiayaan, dan standar penilaian pendidikan. Dua dari ke delapan standar nasional pendidikan ini, yakni Standar Isi (SI) dan Standar Kompetensi Lulusan (SKL) adalah pedoman penting bagi satuan pendidikan dalam pengembangan kurikulum.

Mengorganisasikan

Guru PAI mengorganisasikan kelasnya secara cukup baik. Jadwal pelajaran, pembagian

23I Made Alit Mariana. Pengantar Perencanaan Pembelajaran di Sekolah Dasar. (Denpasar: Lembaga Penjamin Mutu Pendidikan Bali, 2018), h. 4. 
peserta didik, pengaturan formasi duduk, ketertiban kelas, pengaturan tempat duduk peserta didik, penempatan alat-alat, kebersihan, keindahan dan lain-lain mesti dilaksanakan dengan cukup baik. Kondisi kelas yang disiplin namun cukup menyenangkan dapat diterapkan dalam pembelajaran sehingga bisa memotivasi aktivitas belajar siswa.

Memimpin/Menggerakkan

Guru PAI merupakan pemimpin dan penggerak bagi para peserta didik. Kepemimpinan guru lebih memfokuskan pada sikap demokratis lebih memungkinkan terbinanya sikap persahabatan guru dan para siswa dengan landasan untuk saling mempercayai dan saling memahami. Sikap tersebut terlihat bisa membantu membangun iklim yang baik untuk terciptanya suasana pembelajaran PAI, siswa nampak dapat belajar, baik ketika diawasi guru ataupun tanpa diawasi guru.

Berdasarkan observasi dan wawancara dengan WR dan $\mathrm{SM}^{24}$ setiap ada persoalan yang berhubungan dengan sikap peserta didik dan persoalan ekstern lainnya, guru PAI berupaya untuk mencari pemecahan masalahnya agar tanggungjawab guru berfungsi dengan optimal. Menurut SM selaku guru PAI di MTsN 1 Kota Cirebon menjelaskan bahwa ketika pembelajaran berlangsung persoalan itu senantiasa saja ada. Dengan demikian guru-guru PAI melakukan upaya-upaya pencegahan yang dilakukan untuk memecahkan permasalahan-permasalahan tersebut pada saat itu juga. Apabila permasalahan yang ada ialah masalah personal, maka guru PAI mencarikan informasi latar belakang masalah tersebut terjadi. Membantu memberi pemecahan masalah, contohnya dengan mengajak peserta didik untuk berkonsultasi dengan wali kelas atau Bimbingan Konseling dan memotivasi agar peserta didik tetap semangat walaupun sedang ada masalah. Disamping itu guru juga menerapkan pendekatan individu seperti berkomunikasi dengan peserta didik dan menanyakan permasalahan belajar yang mereka hadapi kemudian memotivasi mereka. Untuk masalah pada saat mereka kerja kelompok, umumnya ada saja yang tidak memperdulikan kerja kelompok dan mengganggu. Hal yang guru-guru PAI lakukan memotivasi para siswa mengenai pentingnya kerjasama untuk tercapainya tujuan pembelajaran di kelas.

Upaya guru PAI ini bisa berusaha mencegah yakni dengan cara menyediakan

242 Oktober - 15 Oktober 2019 
keadaan baik fisik ataupun keadaan sosio-emosional sehingga terasa benar oleh para siswa rasa aman dan nyaman untuk belajar. Sekaligus tindakan penyembuhan terhadap perilaku yang melanggar aturan yang terlanjur terjadi agar pelanggaran tersebut tidak berlarut-larut.

Dalam konteks temuan penelitian demikian, penelitian di atas memperlihatkan bahwa hubungan guru dengan peserta didik yang erat meningkatkan keefektifan pengelolaan kelas. Guru merasa lebih berhasil mengarahkan dan menguasai kelas ketika mereka menjadi wali kelas atau mereka merasa dekat dengan peserta didiknya sebab guru tersebut menjadi student advisor. Penerapan teknik-teknik non verbal juga tercatat dalam penelitian ini sebagai diantara usaha efektif yang dilaksanakan guru partisipan dalam menciptakan kondisi kelas menjadi kondusif. Teknik non verbal seperti diam sejenak menghentikan penjelasan, kontak mata, mendekat atau menjauh adalah contoh tindakan yang dilaksanakan oleh guru partisipan. Tindakan yang demikian serta merta menghindarkan keributan dalam kelas dan mencegah keributan tersebut menjadi makin membesar. Teknik non verbal lain seperti gesture yang khas serta tepuk tangan diperlihatkan oleh guru untuk menunjukkan antusiasme terhadap kelas. Catatan ini menggarisbawahi apa yang dijelaskan oleh Bambaeeroo dan Shokrpour bahwa semua bahasa non-verbal bisa digunakan sebagai strategi untuk mengirim sinyal pesan kedisiplinan kepada siswa. Diantaranya ialah dengan menggunakan strategi diam secara efektif justru bisa membuat guru makin memahami apa yang diharapkan oleh peserta didiknya. ${ }^{25}$

Dalam manajemen kelas di MTsN 1 Kota Cirebon dalam pembelajaran PAI, media yang dipakai pada proses belajar mengajar PAI ialah proyektor dan Lembar Kerja Siswa (LKS). Penggunaan media ini cukup membantu dalam mengajar. Disamping itu, umumnya guru PAI menggunakan lingkungan sebagai media.

Penggunaan media memang ikut mempengaruhi lingkungan, kondisi, dan iklim belajar yang dikelola dan diciptakan oleh guru. Pemakaian media pembelajaran dalam proses pembelajaran bisa menumbuhkan minat dan keinginan beraktivitas baru, memotivasi dan rangsangan aktivitas belajar, dan bahkan mempengaruhi psikologis

\footnotetext{
${ }^{25}$ Fatemeh Bambaeeroo, Nasrin Shokrpour, 2017. "The Impact of the Teachers' non-Verbal Communication on Success in Teaching”. Journal of Advances in Medical Education \& Professionalism, 5 (2), 51-59.
} 
terhadap peserta didik. ${ }^{26}$

Dalam pengelolaan kelas pada pembelajaran PAI di MTsN 1 Kota Cirebon bisa dinilai cukup efektif. Hal ini dapat dilihat dari terjadinya interaksi yang cukup baik antara guru dengan peserta didik dan dimaksudkan untuk merealisasikan tujuan pembelajaran PAI dengan cara memfasilitasi keterampilan dan pengetahuan peserta didik melalui kegiatan yang bisa memudahkan dan membantu peserta didik dalam belajar. Interaksi yang baik di sini dalam fakta di lapangan ialah interaksi yang terjadi tidak saja di dalam kelas, namun pula terjadi di luar kelas, sebab keduanya sudah cukup tercipta dalam pembelajaran PAI.

Berpijak pada wawancara dengan MB, guru PAI, ${ }^{27}$ jika dalam interaksi dengan para siswa, ia dengan para guru, terutama guru-guru PAI sampai dengan kepala madrasah telah berjalan cukup baik dan harmonis. Kondisi tersebut ditujukan untuk menumbuhkan kegiatan belajar peserta didik yang positif.

Iklim tersebut terlihat cukup menciptakan kegembiraan dan gairah belajar peserta didik sehingga mereka mempunyai motivasi kuat dan keleluasaan mengembangkan aktivitas belajar masing- masing. Disamping itu, interaksi antar individu yang edukatif cukup terjalin pula pola interaksi yang cukup baik antar guru dengan materi pelajaran, yaitu guru PAI yang kompeten dalam mengajar sehingga proses belajar mengajar berjalan baik dan interaksi antar peserta didik dengan materi pelajaran, yaitu peserta didik yang aktif dan semangat belajar. Terlihat dalam suatu proses belajar mengajar para siswa cukup aktif bertanya terhadap materi PAI yang disampaikan guru yang belum mereka fahami. ${ }^{28}$

Disamping itu, berdasarkan data di lapangan ditemukan fakta bahwa guru mata pelajaran PAI MTsN 1 Kota Cirebon tidak ada yang melakukan pengaturan tata ruang kelas secara utuh, seperti ventilasi cahaya, pengaturan kelas, mengatur kebersihan, pengaturan alat-alat pengajaran, dan desain ruangan, sebab pembelajaran berjalan secara klasikal dan penataan ruang belajar telah tertata sedemikian rupa, dari kondisi kelas yang kecil (penuh) sebab dalam satu kelas berisi kurang lebih 32-35 siswa, maka tidak

\footnotetext{
${ }^{26}$ Sukma Perdana Prasetya. 2018. "Effect of Learning Media Variation to Increase Interest and Learning Outcomes of Geography". Advances in Social Science, Education and Humanities Research, 212, 558-561.

2728 Oktober 2019

2823 Oktober 2019
} 
memungkinkan untuk memindahkan tempat duduk, meja, dan sarana prasarana yang lain, contoh untuk membuat formasi-formasi tempat duduk, sedangkan dari ventilasi dan penerangan semua ruang belajar sudah diatur sedemikian rupa sehingga pengaturan ventilasi dan sumber cahaya jarang dilakukan oleh guru PAI sebab telah ada, akan tetapi ditinjau dari pengaturan di masing-masing kelas telah bisa mendukung dan menciptakan kondisi belajar yang nyaman. ${ }^{29}$ Penelitian mengenai penerapan manajemen kelas diduga paling tinggi $75 \%$ berpijak pada kriteria yang ditetapkan Kriteria Ketuntasan Minimal (KKM) pada sejumlah 33 item intrumen angket dengan 4 pilihan, sehingga 0.75 x $33 \mathrm{x}$ $4=99$. Dugaan ini diuji secara parsial melalui penggunaan formula statistik deskriptif.

Berdasarkan perhitungan statistik, didapatkan skor rerata sebesar 100.7273 : 33 $=3.052342$ yang dikatagorikan sering, dan persentase rerata sebesar 2518.182:33= 76.30855 yang berkategori tinggi. Artinya guru sering implementasi manajemen kelas dengan intensitas tinggi berpijak pada standar proses pembelajaran di MTsN 1 Kota Cirebon atau ada nilai yang lebih tinggi dari nilai yang dihipotesiskan pada populasi (76.30855 > 75\%), sehingga implementasi manajemen kelas di MTsN 1 Kota Cirebon dikatagorikan positif.

Mengendalikan

Guru PAI dalam hal ini penulis nilai sudah dianggap memiliki tanggung jawab yang cukup baik dalam pengelolaan pembelajaran siswa di kelas. Hal terlihat dari upayaupaya yang dilakukan secara kontinyu membangun proses pembelajaran yang mudah ditangkap oleh para siswa, terutama dengan penggunaan berbagai media. Ia juga secara cukup terbuka menerima keluhan siswa atas materi yang terkadang belum difahami, sehingga ia mengulang kembali dengan penjelasan yang lebih sederhana.

Evaluasi

Tahap ini merupakan tahap akhir dari manajemen kelas yang dilakukan oleh guru PAI. Tujuannya adalah untuk mengukur hasil belajar siswa kemudian memberikan penilaian apakah siswa sudah memahami materi PAI yang disampaikan guru, atau guru menilai khususnya melalui pengamatan apakah nilai-nilai Islam sudah cukup tertanam pada diri siswa. Menurut para guru hal ini bisa terlihat dari perilaku sehari-hari selama berada di sekolah seperti kebiasaan shalat dhuhur berjama'ah dan membaca al-Qur'an.

${ }^{29}$ Observasi 23 September - 2 November 2019 
Instrumen yang lain yang lazim dipakai adalah tes terutama untuk mengungkap aspek kognitif siswa terhadap materi-materi PAI. ${ }^{30}$

2. Kegiatan Belajar Pendidikan Agama Islam Siswa

Studi mengenai kegiatan proses pembelajaran siswa mata pelajaran Pendidikan Agama Islam di MTsN 1 Pilang Kota Cirebon diduga (hipotesis) memenuhi standar KKM 75 pada sejumlah 33 item intrumen dengan 4 pilihan jawaban. Artinya ada $0.75 \mathrm{x}$ $33 \times 4=99$. Dugaan ini perlu diuji melalui penggunaan perhitungan formula statistik deskriptif.

Berdasarkan perhitungan yang telah dilakukan melalui uji statistik deskriptif ini, peneliti mendapatkan skor rerata sejumlah $107.2325: 33=3.2494697$ yang berkategori sering, dan persentase rerata sejumlah $2742.052: 33=83.0924848$ yang dikakatogirkan tinggi. Hal ini dapat dimaknai bahwa siswa senantiasa beraktivitas belajar dengan intensitas tinggi berpijak pada standar proses pembelajaran PAI di MTsN 1 Kota Cirebon atau ada nilai yang lebih tinggi dari nilai yang diprediksi pada populasi $(83.0924848>75 \%)$, sehingga kegiatan belajar para siswa di MTsN 1 Kota Cirebon dinilai positif.

3. Pengaruh Manajemen Kelas Terhadap Kegiatan Pembelajaran Pendidikan Agama Islam

Riset mengenai kegiatan pembelajaran para siswa pada mata pelajaran Pendidikan Agama Islam diduga (hipotesis) setinggi-tingginya 75\% sesuai dengan standar KKM pada sejumlah 33 item angket yang disebarkan dengan 4 pilihan jawaban, sehingga $0.75 \times 33$ × $4=99$. Hipotesis ini diuji secara parsial melalui penggunaan formula statistik deskriptif.

Berdasarkan perhitungan statistik, didapatkan persamaan regresi sebesar $\hat{Y}=$ $0.0308901+1.077005(99)=0.0308901+106.6235=106.6544$. Oleh karena itu, diprediksikan bahwa nilai kegiatan belajar PAI para siswa menjadi 106.6545 jika nilai implementasi manajemen kelas dinaikkan menjadi 99.

Persamaan regresi tersebut bisa dimaknai bahwa untuk meningkatkan kegiatan belajar PAI para siswa sebesar 1, maka nilai rerata penerapan manajemen kelas mesti dinaikkan sebesar $99: 106.6544)=0.928231747$. Ini dapat dimaknai bahwa penerapan manajemen kelas efektif untuk meningkatkan kegiatan pembelajaran PAI para siswa

30 Wawancara 23 Oktober 2019 
sebab karena nilai yang didapatkan lebih besar dari nilai yang dikeluarkan (1 > $0.928231747)$.

Hasil temuan di atas menunjukkan bahwa Ha yang berbunyi "implementasi manajemen kelas diduga berpengaruh positif terhadap kegiatan belajar Pendidikan Agama Islam para siswa" dapat diterima atau terbukti secara empiris. Sementara itu, Ho yang merupakan kebalikannya ditolak atau tidak terbukti. Ho dilandasi oleh teori bahwa manajemen kelas yang baik bisa mendorong siswa dalam melakukan kegiatan belajar secara maksimal. ${ }^{31}$

\section{E. Kesimpulan}

1. Implementasi manajemen kelas dalam proses belajar mengajar Pendidikan Agama Islam di MTsN 1 Kota Cirebon sudah berjalan cukup baik. Hal ini dapat dilihat dari secara kualitatif bahwa (1) perencanaan pembelajaran melalui penyusunan perangkat pembelajaran, mengorganisasikan, memimpin atau menggerakkan, mengendalikan, dan evaluasi, (2) pelaksanaan manajemen kelas melalui memotivasi peserta didik untuk aktif, (3) mengkondisikan peserta didik untuk siap belajar, (4) Metode pembelajaran yang tepat dan bervariasi, (5) Media pembelajaran yang sejalan dengan materi yang disajikan, (6) pola interaksi edukatif. Dalam konteks kuantitatif implementasi manajemen kelas di MTsN 1 Kota Cirebon dikatagorikan positif. Hal ini ditunjukkan dari persentase rerata implementasi manajemen kelas sebesar 76.30855\% > 75\%.

2. Kegiatan belajar PAI para siswa di MTsN 1 Kota Cirebon dikatagorikan positif. Hal ini ditunjukkan dari persentase rerata kegiatan belajar PAI para siswa sebesar 83.0924848 $\%>75 \%$.

3. Kegiatan peserta didik belajar Pendidikan Agama Islam di MTsN 1 Kota Cirebon meningkat secara positif signifikan melalui implementasi manajemen kelas. Hal ini dapat dilihat dari uji regresi sederhana menghasilkan persamaan regresi sebesar Ý = $0.0308901+1.077005(99)=0.0308901+106.6235=106.6544$. Hal ini dapat dimaknai bahwa nilai kegiatan belajar PAI para siswa diperkirakan menjadi 106.6544 jika nilai implementasi manajemen kelas dinaikkan menjadi 99 atau untuk meningkatkan kegiatan belajar PAI para siswa sebesar 1, maka nilai rerata

31 Chandra, "Classroom Management for Effective Teaching"..., h. 14; Lewis, "Schooolwide Positive Behavior"..., h. 833-854; Evertson Handbook of Classroom Management..., h. 3-16; Robinson, "Helping Individual Students ....", h. 787-802 
implementasi manajemen kelas mesti dinaikkan sebesar $(99: 106.6544)=$ 0.928231747. Artinya nilai yang didapatkan lebih besar dari nilai yang diperoleh (1 > $0.928231747)$.

\section{Daftar Pustaka}

Asep Kurniawan, Metodologi Penelitian Pendidikan, (Bandung: Remaja Rosdakarya, 2018).

Erik Budianto, "Pendidikan Karakter Melalui Pembelajaran PAI Berbasis Kontekstual", dalam Progresiva, Vol. 4, No. 1, (2010), 125-135.

Fatemeh Bambaeeroo, Nasrin Shokrpour, "The Impact of the Teachers' non-Verbal Communication on Success in Teaching", in Journal of Advances in Medical Education \& Professionalism, Vol. 5, No. 2, (2017), 51-59.

Hamid Tohidi, "The Effects of Motivation in Education", in Procedia - Social and Behavioral Sciences, Vol. 31, (2012), 820-824.

Helen M. Egeberg, Andrew McConney, Anne Price, "Classroom Management and National Professional Standards for Teachers: A Review of the Literature on Theory and Practice", in Australian Journal of Teacher Education, Vol. 41, No. 7, (2016), 1-18.

I Made Alit Mariana, Pengantar Perencanaan Pembelajaran di Sekolah Dasar, (Denpasar: Lembaga Penjamin Mutu Pendidikan Bali, 2018).

Imran Latif Saifi, Muzaffar Hussain, Lubna Salamat, Mohammad Iftikhar, "Impact of Classroom Management on Students' Achievment at University Level", in Asian Journal of Social Sciences \& Humanities, Vol. 2, No. 2, (2018), 13-27.

Jayeeta Bhattacharjee, "Constructivist Approach to Learning-an Effective Approach of Teaching Learning", in International Research Journal of Interdiciplinary \& Multidiciplinary Studies (IRJIMS), Vol. 1, No. 6, (2015), 65-74.

Katharina Sieberer-Nagler, "Effective Classroom-Management \& Positive Teaching", English Language Teaching, Vol. 9, No. 1, (2016), 163-172.

Kiymet Selvi, "Teachers' Competencies", in Cultura. International Journal of Philosophy of Culture and Axiology, Vol. 7, No. 1, (2010), 167-175.

Mohammad AAHM Ali, "The Influence of the Physical Environment on Learning Behaviour: a Case Study of Intermediate Schools in Kuwait", Dissertation, (Birmingham, UK: Faculty of the Arts, Design and Media, Birmingham City University, 2017)

Munawar Rahmat Budi dan Aceng Kosasih, "Efektifitas CD Interaktif dalam Pembelajaran Pendidikan Agama Islam untuk Meningkatkan Hasil Belajar Siswa SMP”, dalam Jurnal Pendidikan Agama Islam- Ta'lim, Vol. 13, No. 2, (2015), 191-200.

Nur Ainiyah, "Pembentukan Karakter melalui Pendidikan Agama Islam", dalam Jurnal alUlum, Vol. 13, No. 1, (2013), 25-38.

Rehaf A Madani, "Analysis of Educational Quality, a Goal of Education for All Policy", Higher Education Studies, Vol. 9, No. 1, (2018), 100-109.

Ritu Chandra, "Classroom Management for Effective Teaching", in International Journal of Education and Psychological Research, Vol. 4, No. 4, (2015), 13-15.

R.M. Oliver \& Reschly D.J., Effective Classroom Management: Teacher Preparation and Professional Development, (Washington, DC: Vanderbilt University, 2007).

Sardiman, Interaksi dan Motivasi Belajar Mengajar, (Jakarta: RajaGrafindo Persada, 2018).

Sarmila Banerjee, Atasi Mohanty, Namita Das. "Impact of Teacher Competence and Teaching Effectiveness on Students' Achievement in Life Science Subject at the Upper Primary Stage", in Journal of Indian Education, Vol. 29, No. 4, (2014), 29-48. 
Steve Olusegun Bada, "Constructivism Learning Theory: A Paradigm for Teaching and Learning", IOSR Journal of Research \& Method in Education, Vol. 5, No. 7, (2015), 66-70.

Sukma Perdana Prasetya, "Effect of Learning Media Variation to Increase Interest and Learning Outcomes of Geography", in Advances in Social Science, Education and Humanities Research, Vol. 212, (2018),558-561. 